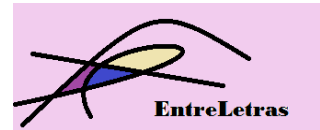

\title{
EDUCATING HUMANS: EMBRACING VULNERABILITY AND RESISTING DECADENCE
}

\section{EDUCANDO SERES HUMANOS: ABRAÇAR A VULNERABILIDADE E RESISTIR À DECADÊNCIA}

\author{
DOI: https://doi.org/10.20873/uft.2179-3948.2018v9n1p32
}

Colena Sesanker ${ }^{1}$

\begin{abstract}
Césaire called a civilization incapable of solving the problems it creates a decadent civilization and Gordon, in his Disciplinary Decadence, demonstrates the decadence of modern disciplines of knowledge production. In their insistence on completeness, anything outside of those totalizing systems are, by definition, problems. This creates problem phenomena: aspects of reality that are therefore not properly understood as reality. Gordon demonstrates that, in order to dismantle the systems of justification that produce intractable problems by denying reality, it is not enough to simply change the content of our education - we must also change the methodology that produces a warped view of reality that cuts us off from all social reality, including the social aspects of ourselves. Gordon's diagnosis of disciplinary decadence has implications for not just what we teach, not just who teaches but, more fundamentally, how we must teach and how we must learn, in order to facilitate liberation.
\end{abstract}

Keywords: decadence; pedagogy; maturity; embodiment; vulnerability.

Resumo: Césaire chamou uma civilização incapaz de resolver os problemas que cria de uma civilização decadente e Gordon, em sua Decadência Disciplinar, demonstra a decadência das disciplinas modernas de produção de conhecimento. Em sua insistência na completude, qualquer coisa fora desses sistemas totalizantes é, por definição, problemas. Isso cria fenômenos problemáticos: aspectos da realidade que, portanto, não são adequadamente entendidos como realidade. Gordon demonstra que, a fim de desmantelar os sistemas de justificação que produzem problemas intratáveis ao negar a realidade, não basta simplesmente mudar o conteúdo de nossa educação - também precisamos mudar a metodologia que produz uma visão distorcida da realidade que nos afasta. de toda a realidade social, incluindo os aspectos sociais de nós mesmos. O diagnóstico de Gordon de decadência disciplinar tem implicações não só para o que ensinamos, não apenas para quem ensina, mas, mais fundamentalmente, como devemos ensinar e como devemos aprender, a fim de facilitar a liberação.

Palavras-chave: decadência; pedagogia; maturidade; forma de realização; vulnerabilidade

${ }^{1}$ Colena Sesanker teaches Philosophy at Gateway Community College and at the University of New Haven in Connecticut, USA. E-mail: colena318@hotmail.com 


\section{Introduction}

Consider the following scenarios:

Zeph: A few weeks into the semester, a student who began life as a white male, and who is prone to dramatic outbursts, declares an overall objection to the course because I (the professor) am "a white man". I stand at the whiteboard with my dark skin andenormous curly 'fro, wearing a waxprint skirt and watch the student storm out of the room.

Tess: During office hours, a student expresses her concern: Mine is the only class in which she is struggling. She gets As. Her GPA is a 4.0. While the delivery is pleasant, there is a clear accusation, and perhaps even a threat in the air. It is clear that she believes the fault is mine. She's good at school, so I must be the one doing it wrong. Good students shouldn't have to struggle.

Joe: During a small-group session at a teaching conference, we are asked to share our teaching philosophies. One group member obediently recites the motto that had been the 'right' answer until recently: "I make sure that I accommodate all learning styles in my classroom" he says. In a quiet moment, I lean in and tell him, softly “Learning styles aren't real anymore”. He looks at me, surprised. I hold up my phone to display an article on the screen, as I hit "send" to text him the link. We both shrug, laugh a little and return to the group activity. The group is now reading an article with a sensational title claiming something that flies in the face of all our experience in the classroom. We are tasked with discussing the implications of this new, shocking research for our teaching. I read further and can tell very quickly that the evidence cited does not support the conclusion drawn. He must have noticed the same thing because, again, we look at each other, shrug, laugh a little, and carry on.

The scenarios above are not presented as typical or characteristic, but will serve to highlight some tensions I hope to identify as products of decadent tendencies and legacies in higher education. Césaire describes a decadent civilization as one that creates problems that it cannot solve. In his book, Disciplinary Decadence, Lewis Gordon describes a decadent academia as a monster that threatens our humanity and yet, because it is "our" creation, some guard it fiercely. 
In this paper, I discuss the implications of Gordon's reflections on decadence, evidence, reason and the political for pedagogy. I will suggest a framework for thinking about these issues in terms of cultivating a balance between power and vulnerability, and demonstrate that these considerations imply that those of us who teach may need to reconceive the classroom and the responsibilities of the professor.

\section{Discipline: cultivating the human}

The Latin root of the term "discipline" means to educate, Lewis Gordon tells us in the introduction to his Disciplinary Decadence. It has since taken on, in ordinary parlance, implications of control and punishment, however. A discipline, as discussed in Gordon's work, is a framework for knowledge production and acquisition. Gordon quotes Dewey in Democracy and Education, connecting the concepts of discipline and power: "Discipline means power at command...Discipline is positive...tend(s) to the development of power to recognize what one is about and to persistence in accomplishment" (DEWEY, 1944, p.129). Those who teach, then, induct students into a knowledge framework which facilitates and shapes their assertion of power. While there is much lamenting about the misuse of power, power itself is not a negative thing. In fact, it is absolutely essential to political engagement: to take one's place as a mature member of a community and to participate meaningfully in shaping and maintaining it in the face of opposition. Power is the "... ability to have an effect on the social world. Power is the ability to live outwardly, to make choices that would initiate a chain of effects in the social world that would constitute the set of norms and institutions that would affirm one's belonging in the world..." (GORDON, 2006, p.105)

We exist in a world with others and, in fact, it is the social world that generates meaning, institutions and forms of life through a process Fanon calls sociogenesis. (GORDON, 2006, 103) Given that the social world brings forms of life and their meanings into existence, it is important to have a measure of power if we are to have any say in the meaning and trajectory of our lives. Those without power do not possess this ability to affect the world beyond what their bodies can touch. The social world, insusceptible to their intentions, calcifies around them, restricting them “...no differently than would a brick wall" (GORDON, 2006, 104) The tragedy is that, though 
capable of choice in virtue of being human, the social world does not provide all persons options commensurate with that capacity for choice and, those who are without power cannot effectively create new options. Those who lack options and who lack the power to create them are the oppressed.

Gordon follows Fanon, claiming that maturity is essential to the human condition (GORDON, 2006, p.89) where maturity is the ability to be actional: to act and achieve outwarddirected effects. A mature individual is capable of political engagement. Political action does not mean simply the exercise of power and control. It requires both the assertion and restraint of power. Mature political engagement happens in a social world of others with competing goals and perspectives and involves participating meaningfully in its construction. In the extreme, one who only asserts power would require that the world conform only to her desires. While mimicking the activity of god, she would in effect, be retreating into her own subjectivity and asking that the world play out her fantasy. This is not an engagement with reality; it is a retreat to the safety of disengagement and delusion. It is not a way of being a human being, but rather a way of mimicking a god.

Being a human being is risky. The Latin roots of "existence" reveal its meaning as deriving from "to stand out" or "to emerge", Gordon reminds us. It requires, for the human being, standing out against a backdrop of others. It is a process of coming to be, as opposed to the stasis of death or non-existence: to really exist is to resist stasis. As long as we exist, we are never completed and therefore never safe. If the story isn't over, we have never already succeeded. There is always more to be done. This is a liberating conception of what it is to be a human being, but it also carries the weight of responsibility. We are perpetually vulnerable to the imposition of others and to the passage of time. This property of resisting containment in any completed story, and of continually unfolding, is what Gordon calls 'metastability'. Human beings, as free, are metastable. This sort of freedom is threatening to those who crave safety, who want the job to be over. To run from one's own metastable existence or that of others - to deny it - is to be in bad faith: it is to lie to oneself about what one is and to retreat from reality.

A discipline, then, ought to facilitate the acquisition of power and, ideally, one's relationship to reality. It ought to support one's development into a mature, full participant in the 
social world. Its goal should be to provide those with the potential the option to choose with the power to do so in a meaningful way. A good education develops free human beings. A good society provides such beings with the option to be actional. In the absence of such a society, a good education prepares free beings to create the society they deserve.

\section{Decadence: Mimicking the Gods}

It is when disciplines or epistemological constructs become decadent that oppression can arise in the discipline. Oppression, after all, is a situation in which a certain type of entity - a metastable human being, capable of choice - is not known as such. A person is taken to be something less than a full and equal member of the humanity of which they are a part. As a result, they are excluded from full membership in the social world - they don't have the option to act on their choices and do not have the power to petition successfully for more options.

A decadent discipline is one which has ontologized its own epistemological structure and therefore acknowledges nothing from outside. Given that there can be no complete and consistent system of knowledge, any such system is necessarily a partial story of reality, masquerading as the whole of it. By definition, nothing can fall outside of a structure that claims to be total - to capture all of reality - and so, those entities and points of view that $d o$ represent an outside present a real problem for said structure's claim of totality. And yet, a decadent system is surprisingly resilient because, despite the fact that academia has purportedly done away with religion in favor of secularity, Gordon points out that the grammar of theodicy remains at the base of our decadent knowledge structures, making them resistant to recognizing their own flaws.

Theodicy is the defense of god as the source of justice - a justification of the existence of an omnibenevolent, omniscient, omnipotent god even in the face of evil. In a theodicy, all appearance of evil is ascribed not to god, but to the failure of limited beings to carry out god's will or to understand god's perfect plan. Original sin and free will are common explanations of the existence of evil.

Secular theory aims to present the objective story of reality, which is to say that it aims to present the story of reality as god would tell it if there were a god. A decadent discipline presumes 
that it is the discipline that, all by itself, has achieved this god's-eye point of view. Anything that falls outside of this story, then, presents a problem for those who take the view to be complete. From the perspective of the discipline, though, given that one accepts its completeness and objectivity, and thanks to the theodicean grammar that remains, entities that present a problem cannot be seen as presenting a challenge to the framework they challenge. If the framework is right, then their presence cannot indicate a problem in the framework; the people who present a problem to the totalizing view must, themselves, be the problem. Those whose appearance or point of view is problematic for the system become problem people. ${ }^{2}$ The decadent discipline, then, is one in which evidence of its incompleteness does not appear as evidence of its incompleteness. It is one in which bad faith is enacted to maintain the belief in its totality.

A decadent discipline makes one resistant to evidence and to reality. It demands greater allegiance to what it says than to what is. If there are enough people wedded to the illusion, it might be perpetuated for a very long time in the illusory world they've collectively created.

Of course there are advantages to having the power to speak epistemic systems and hegemonic orders into existence and to having the social power to remain in that warped reality indefinitely. That is the story of conquest, colonization and domination. For a long time, that power to make it so with one's word was understood as the pinnacle of human action. And yet, history has revealed that it is not without a cost. One cannot hide from reality forever. Eventually, it will reveal itself and you for what they really are.

Decadence, in higher education, occurs when those in one discipline take their own methodology to be the only legitimate methodology. As a result, they ignore any evidence that originates from other sources: other disciplines of knowledge production and the lived experience of those they educate. In doing so, they shut down all possible sources of opposition and of critique. As Gordon puts it, "Dying isn't easy, and it is even more difficult in cases where the process is treated as an indication of good health" (GORDON, 2006, p.10) Dominating the conversation and the absence of challenge have been taken as indicators of the strength of a discipline rather than of its weakness; a sign of its objectivity rather than that of its solipsistic orientation.

\footnotetext{
${ }^{2}$ See Chapter 4 of Gordon's Existentia Africana "What Does it mean to be a Problem: W.E.B. Du Bois on the Study of Black Folk."
} 
Decadent disciplines, then, produce humans who aim to mimic gods. They aim to call reality into being by their very word. They speak all and only the facts. But reality exceeds us. The power an epistemology provides is as a tool for reckoning with reality. Decadence mistakes the tool for reality itself. A non-decadent objectivity is an intersubjective account of reality which takes all perspectives into consideration.

\section{Reality: social and structural conditions that shape the effects of pedagogy}

In the first of the three scenarios with which I began the paper, the course was an introduction to Western philosophy. Western Philosophy is famous for creating problems that it cannot solve. The most sophisticated of us are capable of binding ourselves in theoretical knots in the face of lived evidence that presents a solution. Gordon's solution to Zeno's paradoxes is: just get up and walk away. Zeph did exactly that.

The analytic approach has dominated academia in the US and at the time of Zeph's outburst, we had covered only male philosophers, with similar approaches, addressing reality in a binary and oppositional way that did not account for the existence of gender non-conforming Zeph. In its very form, the methodology denied such existences and provided them the ability to appear only by translating their experiences and cramming them into categories that misrepresent and problematize the reality of existences like Zeph's. Whether or not the reaction was overly dramatic, the observation was accurate. I, in delivering only the tools that would erase the existences of that student and even of myself, was functionally a "white man." I had recreated the epistemological system in which whiteness (or normativity) can arise and push out the other and, as its proponent and instructor, I had placed myself inside it as its gatekeeper. In replicating the totalizing epistemological framework that has been used to justify racism and sexism, my physical existence could no longer stand as evidence against it. I had eclipsed myself.

That Zeph spotted and explicitly rejected this dynamic was unusual. (The reaction was also premature and unwarranted. I knew what I was doing.) Every semester, I watch students navigate the edge - thrilled at the newfound power that mastering the skills of the discipline affords, yet hesitant and wary that the power might prove unwieldy and erase themselves as they know 
themselves to be. Students grapple with the benefits of acquiring new knowledge and new skills, and reconciling these new concepts and methodologies with their own perspective

Learning is growth. It requires that something be left behind. Gordon ends Theory in Black with the following: "Although theory always begins with displacement, its task is to offer an understanding of the place to which we wish never to return because of the one we have found" (GORDON, 2010, p.210) Theory, when successful, should offer us a view of reality that is better than the one with which we started. It should provide a place from which to view reality that feels like home. From such a place, one can interact more effectively and engage more meaningfully.

Decadent theory, though, does not achieve this. It alienates us from reality. It achieves a sort of gentrification of the mind. The displacement to which Gordon refers is not alienation and yet, the effect we, as educators, have on students has not only to do with what we are presenting but with how it is delivered. This how extends beyond our intentions and incorporates the social and embodied reality of the student through which our message is assimilated. Even if we understand our methodologies and concepts as mere tools, students might not receive them as such. It is very easy to intimidate students, to silence them. And there is more than one way to silence a student: some retreat and do not speak at all, but others perform knowledge, producing words without speech and dogma without thought. The epistemological system that functions much like Frankenstein's monster produces the nightmare scenario from a more recent horror movie: Get Out. ${ }^{3}$

This is the case with the pathological A-student: Tess has long since adopted the methodologies of knowledge production and is an expert in the art of mimicry. This affords her great power - she gets the grades she wants, she will demand the future she wants, all because she knows the formula. And yet, should something fall outside of her reach, she deems it unworthy of knowing. It has already been determined that she is smart - she views herself as having come into

\footnotetext{
${ }^{3}$ In Jordan Peele's 2017 film, black bodies are recruited and cultivated only for the purpose of taking on a white consciousness. Likewise, we measure diversity in higher education by counting bodies of color, but not in the diversity of thought produced. (Bryan Van Norden's 2017 Taking Back Philosophy also discusses precisely this problem.) Bodies of color are legitimized by their conformity with a disciplinary structure that was built without their input and often served, intentionally or unintentionally, to silence perspectives like their own.
} 
the education game already complete. Her time there is just a matter of collecting the documentation. The pathological A-student is a product of and an enactment of decadence.

Decadence fosters an insensitivity to evidence. In his discussion of the evidentiality of evidence - that is, the conditions under which evidence is recognized as such - Gordon points out that one reaches for evidence to explain what is missing. "Evidence is summoned, in other words, because of what is absent" (GORDON, 2016). But a system that purports to account for everything cannot acknowledge that anything is missing. By fiat, nothing can stand as evidence for its incompleteness. And Tess, having already contained herself within the descriptor "A-student" acknowledges nothing that would stand as evidence against that. If there is something she cannot master, it must not be worth knowing or it must have been taught incorrectly

Education for the pathological A-student is just a transaction. And yet, who can blame her? Higher education is becoming more and more expensive at the precise moment that it is becoming less and less possible to live decently without a degree. In the US in 2016, the median cost of one year of college at a private institution was more than the median individual income. College is the pathway to a tolerable life, and that pathway becomes inaccessible if grades are not diligently maintained. Perhaps Tess cannot afford a growth opportunity; she cannot afford to be challenged lest she lose it all. She may need a scholarship, or to go on to a competitive graduate or professional program. There are any number of pressures that would put her in a defensive mode. She is here to cultivate and exercise her power in the pursuit of a tolerable life. She has to. What she ultimately gets from her experience is not an education: she amasses weapons. Her approach, according to the majority of Americans, is the smart approach.

What is lost in her experience is the luxury of thinking. As Gordon points out, the word school comes from the Greek for leisure time. Not everyone can afford leisure. Not everyone can afford an education. But everyone must, these days, as long as they are able, get a degree.

It is no surprise, then, that we find ourselves in a supposedly post-truth era in which the line between fact and opinion has been erased and in which news is often delivered as a series of "he said, she said" without reference to reality.

Here, an analogy may be drawn to the medical profession. It should be no surprise that medical doctors, who should have known better, created an epidemic of opioid addiction by letting 
themselves be defrauded by pharmaceutical companies. Medical doctors, some of the more ambitious and entrenched products of our educational system, dismissed the evidence of their own experience because "studies" said otherwise. And, when some pushed back, the term "pseudo addiction" was born: a term that allowed doctors to theorize away what was right in front of their eyes. To make evidence not appear as evidence.

Thus, it is no surprise that learning theories that provide powerful heuristic tools for teaching are ontologized and presented as the facts mimicking the grammar of expertise in the natural sciences and mathematics.

Laziness allows us to mistake a heuristic for reality, and so does the desire for power. ${ }^{4} \mathrm{As}$ educators, ourselves products of this system, we must continually cultivate our own maturity and face our own status as metastable: experts or no, we are not done. In the fourth of his letters to those who dare to teach, entitled "On the Indispensable Qualities of Progressive teachers for their Better Performance," the very first quality Friere lists is humility. Humility, as he tells it, is the courage to really listen even to those who are considered less competent. "Humility helps me avoid being entrenched in the circuit of my own truth. One of the fundamental auxiliaries of humility is common sense, which serves to remind us that certain attitudes may lead us too close to becoming lost" (FRIERE, 1998, p.40). Humility is counter to decadence. It requires that we remain vulnerable to points of view and to evidence that can undermine our authority. It requires that students' reality is taken seriously. It is what is required by what Lewis and Jane Anna Gordon put forward as the Pedagogical Imperative: the position that teaching and learning require constant articulation of reality's vastness.

\section{Pedagogy as political engagement}

\footnotetext{
${ }^{4}$ The study we were looking at was implausibly terrible. And yet, it was just easier to go with the flow. It would have been obnoxious to interrupt and criticize. I took it with me and shared it with my logic class. We had a conversation about how the publish or perish culture of academia might incentivize someone to make up a sensational title in spite of the fact that their experimental design had no bearing on such a claim, about the problem of replication in education research, and about the need for science journals to disclose both rejected and accepted studies so that statistical anomalies are not mistaken for the norm.
} 
One does not teach disembodied minds. Students are embodied beings who are already entrenched in a ruthless social world. The material conditions of reality do not wait outside the door while we teach. They enter and shape what we say and how it is received. These material conditions prime students. They determine whether students reach out for only the power of the tools or open themselves up the vulnerability and humility of facing reality. They determine whether the choice between the two is, for any given student, a viable option.

If we are interested in liberating rather than colonizing minds, our intentions are not enough. Social conditions matter. For educators too, the choice between the two approaches might amount to a non-option. Whether the option exists is a function of the embodied and social conditions in which students and teachers find themselves. As he puts it, "the legacy of colonialism is the necessity of a politics for an ethics"(GORDON, 2010, p.208) The tragedy of an unjust system is that the political precedes the ethical. We are living in such a system. Training a workforce of indentured servants is very different from educating a populace of free, self-governing citizens. We have to choose what kind of future we want in order to equip students to choose what kind of future they want. We may have to acknowledge that our cultivating the capacity to exercise freedom and power might be met with few options to actually do so and, ultimately, result in frustration. We have to decide whether we prioritize developing free beings or objects that will be useful to employers.

In a politics of recognition, those disadvantaged by the system appeal for acknowledgement and inclusion, but a decadent structure cannot recognize such appeals. As we have seen, they do not function as evidence that the system has problems, but simply as problems. If those excluded by the structure hope to make the evidence of their aspect of reality evident to a decadent system, they would have to translate that reality into a grammar that functions to conceal such evidence and so, their only hope for recognition lies in self-negation. Perhaps one might hope that the paradoxical existence of a self-negating (doubly conscious) subject would force the deluded to recognize what they can already see. But, like the discovery of Neptune, their existence is usually written off as an anomaly or a case of mis measurement until there is a theory capable of capturing the phenomenon. 
Gordon suggests that, instead of seeking recognition, we create the environments in which those who are excluded can be recognized by creating new kinds of inclusive institutions and alternative spaces. In the case of making space for black philosophers in the academy, he talks of "the revolutionary risk-taking of not worrying whether something really 'is' philosophy or not..." (GORDON, 2006, p.114)

In academia, generally, there is a need to build spaces that nurture thought and to reform structures and institutions that would produce indentured servitude. Business models influence the classroom. Where tuition is high, very little of the tuition goes into the classroom and, instead, corporate alliances are prioritized to ensure that students can repay their loans once they graduate. Inevitably, students who are not wealthy may look to education for social power and avoid additional vulnerability. Those who thrive do so in spite of the conditions. ${ }^{5}$

Beyond the intentions of individual educators, the structure of an institution can be a competing force that frustrates rather than facilitates a healthy education. Beyond the ideals of the institution, market demands determine what is responsible, or even possible. There is a need to create new sorts of spaces and to fight to reclaim those that have been lost to the totalizing corporate system that acknowledges only value that is measured in countable, tradable objects. It is well worth asking questions about what can be done here to create spaces that facilitate the cultivation of liberation, reason and thought.

\section{Pedagogy as embodied engagement}

One form of decadence is a philosophy that explicitly takes the ideal of human reason to be mimicry of a disembodied mind and the ideal of human morality to be modeled on that of an unlimited deity. This conception of the ideal of humanity is at the base of western culture and has, no doubt, shaped the methodology of higher education. While there is a push toward inclusion and diversity on some fronts, methodology remains relatively stable. For example, though ancient traditions that emphasize physical discipline are taught, the mode of delivery is often that of talking

\footnotetext{
${ }^{5}$ Elite institutions with large endowments have less of this pressure and so rather than equalizing class divisions through education, we may be moving toward further entrenching them.
} 
about the fact that the foundation of such a discipline is that practice precedes understanding. We talk that claim to death in an effort to intellectualize what is an explicit rejection of intellectualizing. An inherently bottom-up approach is delivered in a top-down fashion because of the restricted conception of what knowledge should be within academia.

Incompleteness proofs in mathematics and critiques of ethics are among the evidence available that what is meaningful exceeds that which can explicitly be conveyed in language. If alternative traditions claim to provide answers to the very questions we investigate, it is worth exploring them on their own terms. Experimental philosophy, in which philosophy borrows from the methods of science, has come to be included in a handful of philosophy departments in the last twenty years or so and interdisciplinary projects are becoming increasingly common. Other methodologies, borrowed from the methods of non-academics, should also be considered if they hold the potential to answer the very same questions we are asking.

Decadence creates problems it cannot solve, often simply because it refuses to acknowledge solutions it does not (and cannot) itself produce. As Gordon draws the distinction, while rationality and reason have often been conflated, reason is much broader than rationality. "the conquest of reason by rationality would mean the end of thinking" (GORDON, 2006, p.126). Thinking is more than just intellectualizing. The activity might look different from what is typically expected.

I take the transdisciplinarity Gordon calls for to include subjects that have not traditionally been taught on their own terms as philosophy in a university setting. This includes physical forms of yoga and methodologies that are typically dismissed as mysticism. ${ }^{6}$ The expansion of disciplinary languages requires a teleological suspension of disciplinary decadence that should include, I suggest, physical expression.

\section{Education as cultivation of power and vulnerability}

\footnotetext{
${ }^{6}$ This is consistent the way Paget Henry discusses transmutation of double-consciousness into the liberating capacity of potentiated second sight: the very same reality deployed under a different engagement with reality produces actional potential. Double-consciousness can be debilitating if we understand reality as static. It can be liberating when redeployed, from the position that we are metastable, as potentiated second-sight. A Sadhana is the practice of mindfully orienting oneself to reality.
} 
The paradoxes at the base of philosophy tell us that, ultimately, its value and justification is found elsewhere: in the lives of those who seek wisdom. Philosophy and knowledge production is for human beings. The pursuit of knowledge would be unnecessary for gods.

Developing a measure of power is necessary for human existence. Cultivating vulnerability is also necessary for existence as human. Vulnerability is a sensitivity to evidence and to others; it is susceptibility to being wrong or to being challenged and an openness to doing what it takes as dictated by the conditions in which one finds oneself. A healthy discipline is one that cultivates both power and vulnerability simultaneously, and thereby evades collapsing into decadence. And by the same token, a healthy educator is one who continuously cultivates both power and vulnerability in themselves and in those they educate. The job is never done.

\section{References:}

CÉSAIRE, Aimé. Discourse on Colonialism. Monthly Review Press, 2000.

FREIRE, Paulo. Teachers as cultural workers: Letters to those who dare to teach.

GORDON, Lewis. Disciplinary decadence: living thought in trying times. Paradigm Publishers, 2006.

. Theory in black. Teleological suspensions in philosophy of culture. Qui Parle: Critical

Humanities and Social Sciences, volume 18, number 2, p.193-214, Spring/Summer 2010.

. A very short reflection on the evidentiality of \#Evidence.Allegralaboratory.net,

November 2016. 